\title{
Nursing care in postpartum adaptation: perceptions of Brazilian mothers
}

\author{
Tatiane Hammes ${ }^{1}$, Luciara Fabiane Sebold ${ }^{2}$, Silvana Silveira Kempfer ${ }^{2}$, J uliana Balbinot Reis \\ Girondi $^{2}$ \\ 1. Nurse. Centro Universitário para o Desenvolvimento do Alto Vale do Itajaí. Santa Catarina, Brazil. 2. Federal University \\ of Santa Catarina, Santa Catarina, Brazil.
}

Correspondence: Luciara Fabiane Sebold. Address: Street of Roses, 685 Grove Mansion, Sao J ose, Santa Catarina, Brazil. Email: fabisebold@gmail.com.

Received: June 23, 2014

DOI : 10.5430/jnep.v4n12p125
Accepted: September 23, 2014

Online Published: October 19, 2014

\section{Abstract}

Background: Women's health is a topic which is being focused on by public health policies in Brazil; discussions are increasingly expanding and receiving special attention. There are numerous campaigns and actions developed on the importance of preventive screening before birth as well as humanization of childbirth and breastfeeding. Objective: to identify the needs of mothers regarding postpartum nursing care.

Method: Qualitative research Convergent Care type held with mothers in a city of Santa Catarina - Brazil. Twenty-three semi-structured interviews took place during October 2012.

Results: Postpartum is an important moment on women life. Women's need adapt in the new conditions as mother and describes some experiences and difficulties such feel physically tired, have pain, difficulties to breastfeeding, problems to conciliate work and newborn. The participants related that received more physicians' assistance than nurse assistance.

Conclusion: Puerperium causes sudden changes in women's lives; the transition from being pregnant to being a mother is sometimes a difficult period, which demands maternal adaptation, requiring physical and emotional balance. It is important that nurses are aware of the difficulties and needs of these women, in order to provide qualified midwifery attention.

\section{Key words}

Women's health, Nursing care, Postpartum period

\section{I ntroduction}

Women's health is a topic being focused on by public health policies in Brazil; discussions are increasingly expanding and receiving special attention. There are numerous campaigns and actions developed on the importance of preventive screening before birth as well as humanization of childbirth and breastfeeding. However, attention to women's health during the postpartum period is still surrounded by myths and cultural beliefs.

During pregnancy biological, physical, psychological and social changes take place, influencing the individual psychic action and social relationships of the pregnant woman and the way she experiences these changes. This may result in intense reflection upon motherhood and the mother-infant relationship ${ }^{[1]}$. 
After childbirth, women start to experience the postpartum period, which is the period in which the female body changes caused by pregnancy return as they were, i.e. the body returns to its pre-pregnancy state. These changes strongly impact on women's lives, as they not only interfere in their biological and physical state, but also on their interpersonal and family relationships, thus the need for puerperal adaptability. This period demands physiological and psychosocial care, so that women can foster self-care and at the same time is able to provide skilled care to her child ${ }^{[2]}$.

Therefore, health professionals' care, especially nurses, is of utmost, as they can contribute towards women's best adjustment during this period, and professionals need to be grounded in technical and scientific knowledge to provide skilled care.

The puerperium being a period of risk, skilled nursing care is then essential, based upon the prevention of complications, physical comfort and emotional and educational activities that will endow women with tools to take care of herself and her child. These actions might be alternated by careful listening and appreciation of the specific demands of women who are influenced by social expectations concerning the pursuit of motherhood ${ }^{[2]}$. Careful attention must be taken, as in many cases, nursing care is focused only on the newborn and the mother, who until now received full care and attention, has a supporting role position, where taking care of the child is the main function.

Therefore this study aimed at identifying the need for nursing care during the immediate postpartum period.

\section{Method}

A qualitative study of convergent assistance approach, held in Rio do Sul, Santa Catarina - Brazil, at maternity Fundação de Saúde do Alto Vale do Itajaí - FUSAVI (Alto Vale do Itajaí Health Foundation). This ward has twenty-five SUS beds (Unified Health System). This maternity unit assists a monthly average of 160 patients.

Subjects of the study were 23 mothers: aged 19-35; having a vaginal or caesarean childbirth and who were hospitalized during the first 48 hours after labour. The schooling background of the mothers was between elementary school to postgraduate level, where the majority had completed high school. Labours experienced totalled 11 normal deliveries and 12 caesarean sections; 13 were primigravida and the others multiparous.

Data collection was by semi-structured audio-recorded interview, later transcribed. The women's interviewed were identified with the letter P (postpartum) in ordinal manner (P1, P2, P3...).

As technical analysis of data, Bardin analysis content was used, which is the set of analysis techniques for communication, using systematic and objective procedures to describe the content of the messages to obtain indicators, either quantitative or not, that will nurture the inference of knowledge on the conditions of production/reception of these messages ${ }^{[3]}$.

The study was approved by the Ethics Committee on Human Research of UNIDAVI, under protocol number 977/2012 and by the institution under study. All interviewed women provided written consent.

\section{Results and discussion}

It is important to reflect on issues surrounding the puerperium; several studies lead to the importance of nursing care during this stage. The puerperium assistance aims in monitoring changes related to this period, to alleviate discomfort and to prevent conditions that can lead to puerperal morbidity and mortality ${ }^{[4]}$.

During puerperal assistance some goals are established, amongst which the following can be highlighted: verifying women and newborns' health status; assessment, support and encouragement towards breastfeeding; family planning 
guidance; identifying risk situations and complications thereof and management of these situations; assessment of the interaction between mother and new-born and finally, contemplation of actions that were not performed during prenatal stage $^{[5]}$.

Care provided by nurses is extremely important; nurses ought to have extensive knowledge about changes occurring during the postpartum period given its complexity. Therefore, interpersonal assistance should be rendered, according to the real needs of women, duly respecting individuality and life context of each woman ${ }^{[6]}$.

It is imperative that the puerperal woman has access to qualified care, in which it is possible to share their anxieties, needs as well as the ability to clarify their doubts, in view maturing this new stage in life ${ }^{[7]}$.

In this perspective nursing care is related to four adaptive modes, as women undergo physiological, self-perception, role and interdependence functions.

Therefore, nurses should aim to maintain balance of physiological functions and to conduct guidelines to promote the stability of other adaptive modes according to the situation of each woman.

\subsection{Caring adaptations to the new-born}

Postpartum period is an extremely valuable time in women's life, where care is focused on the newborn and there are expectations, from surrounding people, for the new life that has arrived. It's important to highlight that time and word are demanded from the mother catering the needs of the child, which may result in sleeping disorders, fatigue and agitation ${ }^{[22]}$.

Taking care of the newborn involves bathing, breastfeeding, immunization, newborn screening, care for the umbilical stump, amongst others. It was observed that dressing of the umbilical stump and bathing were items that most concerned women. Caring for a newborn means aiding him/her to overcome the most vulnerable stage of human life when the intrauterine life to extra uterine transition occurs. Nursing staff must work on mother and child together, as from birth they both part of each other's lives ${ }^{[20]}$.

Immediate puerperium is important for bonding between mother and child. In this period health professionals need to enhance their listening skills and pay close attention to mothers. Mothers are open to new learning, a process where guidance and support are essential ${ }^{[23]}$.

Amongst such caring is breast-feeding. Breastfeeding is an act of love, care and health, in which mother and child create unique ties. Breastfeeding requires time and dedication from the mother; women need to adapt themselves to this new gesture that can sometimes be physically or emotionally difficult. The benefits of breastfeeding are countless, amongst which the reduction of child mortality, morbidity from diarrhoea, infections, rates of hospital admissions, protection against allergies, obesity control, cardiovascular disease, leukaemia, lymphoma, better nutrition, better cognitive and motor development, savings and increased bond between mother and child ${ }^{[24]}$.

Breastfeeding is one of the first interventions to promote child health done by the mother to ensure quality of life; this is the most natural and suitable act to feed the infant, besides providing biological and emotional basis for both. This process while enjoyable, can also be stressful for the mother who is exclusively engaged in this activity, which can result in happiness, excitement, fatigue, anxiety and in situations where the woman does not achieve the expected success, it can be frustrating ${ }^{[14]}$. Some interviewees were aware that they would need to adapt to this new activity:

"Learning to breastfeed [...] breastfeed for me is the most important". (P8)

"I’d say difficulty in breastfeeding, because I did not nurse the first child, so I do not really know how to deal with breastfeeding and he wants to be nursed all the time”. (P16) 
When facing the maternal transition role, breastfeeding is considered as an event beyond a biological view, as it is influenced by social, political, economic, cultural and emotional factors. Breastfeeding should be considered as a complex act resulting from features and particularities defined by nature and culture. In many situations the puerperal women need to learn how to succeed in exclusive breastfeeding ${ }^{[25]}$.

To Roy the ability a person has to adapt to a new task can be a threat to their social integrity, and the nurse should be concerned about this threat and assess whether the mode of adaptation is favourable or not ${ }^{[16]}$.

Breastfeeding is usually initiated with the assistance of professionals at the hospital and to be continued in home. However, the postpartum period that is in the hospital is short and it effectively occurs after discharge. Consequently, it becomes imperative that the puerperal women are prepared to play this role. It is important that practitioners do not only consider the importance of breastfeeding and its incentive programs, but value breastfeeding women, their history of life, feelings, values, believes as well as social and economic contexts ${ }^{[25]}$.

It is important that nurses prepare the puerperal women to a healthy breastfeeding, teaching correct techniques and providing guidance to answer questions, clarify possible myths and taboos that may hinder this act and thereby assist in their adaptation. Nursing care must now overcome technical barriers and awaken the true meaning of breastfeeding for women; nurses must respect, however, the desire to breastfeed the child or not.

Some mothers need guidance to other care related to newborn, as verified in the statements below:

"Baby care is a special care". (P6)

"I don't know how to bathe and I learned to clean the navel with alcohol that I did not know". (P8)

"I came here [...] they came and helped, to bathe, to burp and put the knack of sleeping”. (P9)

"Bathing, changing the diaper and to suckle we do not know well, I don't know how to bathe, I was afraid of hurting the navel”. (P11)

Nursing care of women in the postpartum period is very important because it represents a moment that requires discussion and guidelines that enable achievement of humanization of care, promoting comprehensive care. A multidisciplinary action should be performed with the aim of clarifying doubts and helping mothers about newborn care ${ }^{[26]}$.

When analysing maternal reports, it can be observed that some women demonstrate insecurity and fear regarding newborn care. Nursing staff, particularly nurses, hold a key role in guidance; they ought to possess knowledge to share with mothers and thereby assist them in care, clarifying doubts, being present during this period of insecurity and uncertainties, which can strengthen the adaptive process of women on such special period of life.

\subsection{Physiological adaptations}

The postpartum period results in biological, psychological and social changes for the woman, being a period of vulnerability, where she needs help from health professionals as well as her families, taking into consideration that care must not end after labour ${ }^{[8]}$.

After delivery, relevant phenomena, of hormonal, psychological and metabolic nature take place, occurring purely from involution actions, and others, on the contrary, are related to synthesis and anabolism. This period is understood as a moment of utter importance for women because it is at this stage that the female body, as well as reproductive organs altered by pregnancy and childbirth, gradually return to its pre-pregnancy state ${ }^{[9]}$. Women undergo intense psycho-organic adaptation changes, where the involution process of the reproductive organs to the pre-pregnant stage, early lactation and the occurrence of abundant emotional changes ${ }^{[10]}$. 
One of the physiological aspects that happen during this period is pain. Pain relief is objectified as a basic right to all, so it is not just a clinical issue, but also an ethical situation involving all health professionals who take care of postpartum women ${ }^{[11]}$.

After a caesarean section, pain can restrain recovery and interaction between mother and newborn, being an obstacle for proper breastfeeding positioning, to perform self and child care as well as everyday activities such as sitting, standing up, walking and carrying out personal hygiene. During this time pain can be characterized as acute, with sudden onset and unpredictable end, being overall related to tissue trauma that generates inflammatory reactions ${ }^{[12]}$.

"Physically I am in pain. I thought it was going to be a little easier". (P3)

"Physically weakened, [...] with much pain”. (P4)

"Physically not so well, because it hurts and drives one crazy [...] but the whole body hurts, stitches and all”. (P11)

"Now the postpartum period is painful and there are all things you need to weigh the pros and cons". (P12)

Pain felt by women who underwent vaginal delivery was somewhat different from that felt by women who had caesarean section; this information results from testimonies of mothers who compare situations:

“The body aching after caesarean delivery is quite complicated”. (P18)

"The pain is worse than if it had been a normal delivery I think [...] I am in pain, everything we do is hindered, if it was a normal delivery...” (P22)

It is important to remember that puerperal women from caesarean delivery have a peculiarity when compared to other patients undergoing surgeries, as they need to move more in order to take care of the newborn, prone to feel more pain on the surgical incision ${ }^{[12]}$.

Pain can lead to women having difficulties in healthily exercising the role of motherhood, with impact on daily activities as well, such as self-care and breastfeeding. Pain also interferes with sleep, resting, moving, urination, bowel movement and appetite of the puerperal women. These difficulties can cause physical, psychological and emotional problems, giving a negative view of parturition ${ }^{[12]}$.

Although a major complaint by women, pain is often devalued by health professionals, family members and even by the puerperal, as the newborn is now the priority.

Considering that pain can hinder puerperal adaptation, as well as care for the newborn, nursing staff should be aware of the level of pain presented by women, subsequent pain control and the ability to create strategies to reduce discomfort, favouring adaptation thereof. In moments of pain, nursing care may comprehend the physical aspect, such as bathing assistance, improving comfort in bed, relaxation massage, as well as words of encouragement and care.

Nursing may, however, also contemplate treatment with drugs, oral analgesics, anaesthetics and either cold or hot sitz baths be taken. Advice on causes of pain is also essential. In many cases women can confuse experienced pain with gas pain, especially after a surgical labour or when constipated. Identification of cause of pain assists in relieving symptoms ${ }^{[13]}$.

It is a priority that health professionals not only identify morbidities postpartum, but value them, pain in particular, and that methods that aim in reducing suffering, allowing the woman to have a positive experience of both childbirth and motherhood be undertaken. To evaluate pain in an increasingly common procedure in hospitals, and thriving to know more precisely about this symptom may qualify a caring model and also aid in developing more effective analgesic routines for 
proper pain treatment, thus promoting a broader humanized puerperium care. Nursing care can consequently be accomplished through nursing observation, dialogue and knowledge, to identify pain level and intervene in reducing pain following analysis.

Fatigue was another physiological aspect described by interviewees, as follows:

“I’m just tired”. (P2)

"Physically tired, really tired". (P5)

In early postpartum period, women may experience some physical discomfort; tiredness results from efforts expended during labour ${ }^{[14]}$.

Resting is extremely important for both physical and mental health of the postpartum women. Dealing with the joys and dedication to a new family member who is totally dependent, can be an impossible task for a tired mother ${ }^{[15]}$.

Fatigue is, therefore, a factor that can interfere on many aspects of motherhood, amongst them and more importantly effective breastfeeding, maternal self-care and needed care to newborn. Thus, it is important to instruct mothers to rest whenever the child falls asleep, to eat healthily and to hold adequate fluid intake.

Nursing care and guidance can provide a calm environment that encourages women to relax, rest, sleep and drink plenty of water so that physiological integrity is reinforced. The nurse should advise the mother to sleep whenever the newborn is doing so, because once awake, some activities will take place; emphasis must be given to the fact that breastfeeding largely consumes energy, whereby women ought to be invigorated and refreshed.

\subsection{Family adaptations}

According to Roy, patients correspond to a biopsychosocial being living in constant interaction with a changing environment. Thus, one is always changing and trying to adapt to these changes. To this end, one uses mechanisms that may be either innate or acquired ${ }^{[16]}$. For Roy, one of the adaptive responses is the performance of roles that specifically focuses on the roles that the person occupies in society. The basic need has been identified as social integrity for individuals and clarity of roles for human groups ${ }^{[17]}$.

A deeper knowledge on how women experience the postpartum period and factors affecting their adaptation is of paramount importance, so that nursing team interventions may contribute towards improved quality of life ${ }^{[8]}$.

When asking mothers about adjustments needed following the arrival of the child, domestic and family activities were priorities:

"Usually I did what I wanted when I wanted, so now I'll need to work by him [...] I'm putting in my head that I will need to adapt”. (P3)

“Now it’s a new life routine”. (P4)

During the stage encompassing pregnancy to labour women receive full attention, being in a state of plenitude and power; after delivery, however, the focus is switched to the child. Therefore, puerperal women need to adapt to new conditions of life, and may present personal needs that are not immediately identified by the nursing staff. Is in immediate postpartum that occur major anatomical, physiological and psychological changes in the women, in this time women have more difficulty to adapt a new life and at this moment suffer more social pressure to assume mother's role ${ }^{[18]}$.

When generating a child, women take the initial responsibility of caring for this child, devoting most of their time to this task $^{[19]}$. In this context, family organization and other responsibilities are modified to so that they can adapt to new living 
conditions. With maternity, women are granted with a new prestige of being a mother, a transition that demands a redefinition of roles and the need for personal adjustments and amendments. A stage of psychosocial changes happens in their lives; these changes depict the need for adjustments in their daily household ${ }^{[8]}$.

The arrival of a new member in the family may increase family tension, which results in the need of reorganization of roles and rules within the family. The birth of a child is an important milestone in the family life cycle and may significantly influence established balanced. As verbatim below:

“Caring more than I took care of the house and my children”. (P8)

"I will undergo major transformations in the family bond, the daily routine". (P15)

Women undergo gradual adaptation from being pregnant to being a mother; this adaptation varies from woman to woman, and some factors are relevant at this point, such as how many children the woman has, her childhood, her relationship with her parents, the experience of pregnancy, the relationship with the child's father, her self-concept, among others. Nurses should use these factors to evaluate the puerperal woman ${ }^{[15]}$. Although no longer pregnant, her body has not yet returned to pre pregnancy condition, her uterus is still enlarged; both her physical and endocrine systems are undergoing major changes. In first pregnancy the women experience a transition, she is no longer pregnant and became a mother, although she does not feel like a mother yet and might not know what being a mother really is ${ }^{[15]}$.

\subsection{Professional adaptations}

The arrival of a new member in the family may also influence the ideal profession, or even that job needed to support and sustain the family, changing routines or professional dreams, as reported:

"A lot, and indirectly the woman always takes greater responsibility in raising the child, so if you need to change jobs or if you need to change anything in life, the responsibility is yours”. (P10)

"You have to learn to take care of him and work, is not too easy". (P12)

For a long time, the female figure was directly related to the duties of wife and mother, however many women saw this symbol as an obstacle to personal fulfilment. Over time, female engagement became professional as well, in order to correspond to self-concern as well as desires of expression and self-fulfilment ${ }^{[20]}$. In the last decades, female participation in the labour market rose relatively, ensuring women's contribution to family income. In addition to professional activities, many women are responsible for most household chores and children care. Reconciling these responsibilities can be complicated due to the number of activities and the great demand required by work and family ${ }^{[21]}$.

The professional issue is another question women will need to adapt, in order to combine professional work with maternal duties or momentarily abdicate a career to devote more time to the new family member.

Following Roy's theory of adaptation, if the person is experiencing problems related to the role being fulfilled, these effects may interfere in cure and good health, hence nurses must evaluate, diagnose and intervene in order to promote adaptation and to assist any difficulties ${ }^{[16]}$. Nurses will be able to help adaptation of postpartum women in the sense of reflecting their new social and professional condition, helping them to seek solutions to better adaption of family and the new member.

\section{Conclusion}

Puerperium causes sudden changes in women's lives; the transition from being pregnant to being a mother is sometimes a difficult period, which demands maternal adaptation, requiring physical and emotional balance. It is important that nurses are aware of the difficulties and needs of these women, in order to provide qualified midwifery attention. Identification of 
both history and culture of puerperal women needs to take place, so that guidance can take place according to their beliefs and needs, so that these women develop a satisfactory adaptive response and feel safe to take care of herself and her child.

Nursing care during postpartum represents a major challenge for nurses, in view it's not only the physiological aspects that women face during postpartum period, but also the psychological aspects and new adaptations in relation to family and professional life. Such understandings, as well as others, must guide health professionals - nurses in particular - in rendering individual, human and holistic care ${ }^{[27]}$.

This study discussed about some aspects of postpartum and nursing care, but the results do not represent all about this theme, we suggest more studies to clarify this moment in mothers' life and your needs, as well as nursing practice.

\section{References}

[1] Piccinini CA et al. Gestação e a constituição da maternidade. Revista Psicologia em estudo. 2008; 13(1): 63-72. http://dx.doi.org/10.1590/S1413-73722008000100008

[2] Teixeira CS. Momentos de verdade da assistência de enfermagem à puérpera: um enfoque na qualidade. Revista Enfermagem UERJ[Internet]. 2010; 18(3):429-34. Available from: http://www.facenf.uerj.br/v18n3/v18n3a16.pdf

[3] Bardin L. Análise de conteúdo. São Paulo: Edições 70, 2009.

[4] Melson K et al. Enfermagem materno-infantil: Plano de Cuidados. 3. ed. Rio de Janeiro: Reichmann \& Affonso, 2002.

[5] BRASIL. Ministério da saúde. Secretaria de Atenção à Saúde Departamento de Ações programáticas Estratégicas. Pré-natal e puerpério: atenção qualificada e humanizada - manual técnico. Brasília, DF, 2006. Disponível em:

[6] Rodrigues DP, Pagliuca LMF, Silva RM. O domicílio como espaço educativo para o autocuidado de puérperas: binômio mãe-filho. Revista Texto \& Contexto de Enfermagem. 2006; 15(2): 277-286. http://dx.doi.org/10.1590/S0104-07072006000200012.

[7] Oliveira JFB, Quirino GS, Rodrigues DP. Percepção das puérperas quanto aos cuidados prestados pela equipe de saúde no puerpério. Revista Rene[Internet]. 2012; 13(1): 74-84. Available from:

http://www.revistarene.ufc.br/revista/index.php/revista/article/view/19/15.

[8] Merighi MAB, Gonçalves R, Rodrigues IG. Vivenciando o período puerperal: uma abordagem compreensiva da Fenomenologia Social. Revista Brasileira de Enfermagem. 2006; 59(6):775-779. http://dx.doi.org/10.1590/S0034-71672006000600010.

[9] Cabral FB, Oliveira DLLC. Vulnerabilidades de puérperas na visão de equipes de saúde da família: ênfase em aspectos geracionais e adolescência. Revista Escola de Enfermagem USP. 2010; 44(2): 368-75. http://dx.doi.org/10.1590/S0080-62342010000200018.

[10] Strapasson MR, Nedel MNB. Puerpério imediato: desvendando o significado da maternidade. Revista Gaúcha de Enfermagem[Internet]. 2010; 31(3): 521-8. Available from: http://seer.ufrgs.br/index.php/RevistaGauchadeEnfermagem/article/view/12897/10883 PMid:21574338 http://dx.doi.org/10.1590/S1983-14472010000300016

[11] Varella RSQ. Avaliação da dor no pós-operatório de cesariana através da utilização do questionário de mcgill. Rio de Janeiro, 2011. Dissertação (Mestrado em Saúde da Criança e da Mulher) Fundação Osvaldo Cruz. p.12

[12] Souza L, Pitangui ACR, Gomes FA, Nakano AMS, Ferreira CHJ. Measurement and characteristics of pain after cesarean and its relationship with activity limitations. Journal Acta Paulista of Nursing. 2009; 22(6): 741-747. http://dx.doi.org/10.1590/S0103-21002009000600003

[13] Fraser DM, Cooper MA. Assistência obstétrica: um guia prático para enfermagem. Rio de Janeiro: Elsevier, 2010.

[14] Zampieri MFM, Garcia OR, Verdi M, Boehs AE. Enfermagem na atenção primária à saúde da mulher. Florianópolis: UFSC/NFR/SBP, 2007.

[15] Ziegel EE, Cranley MS. Enfermagem obstétrica. 8 ed. Rio de Janeiro: Guanabara Koogan, 1985.

[16] Silva JV, Braga CG. Teorias de enfermagem. 1 ed. São Paulo: Látria, 2011.

[17] Rodrigues DP, Pagliuca LMF; Silva RM. Modelo de Roy na enfermagem obstétrica: análise sobre a óptica de meleis. Revista Gaúcha de Enfermagem[Internet]. 2004; 25(2): 165-75. Available from: http://www.seer.ufrgs.br/RevistaGauchadeEnfermagem/article/viewFile/4503/2440 PMid:15683005

[18] Centa ML, Oberhofer PR, Chammas J. Puérpera vivenciando a consulta de retorno e as orientações recebidas sobre o puerpério. Revista Fam. Saúde e Desenvolvimento. 2002; 4(1): 16-22. http://ojs.c3sl.ufpr.br/ojs2/index.php/refased/article/view/5061/3828.

[19] Figueiredo MA. Ensinando a cuidar da mulher, do homem e do recém nascido. São Caetano do Sul, SP: Yendis, 2005. 
[20] Smeha LN, Calvano L. O que contempla uma mulher? Um estudo sobre a relação não-maternidade e vida profissional. Revista Psicol. Argum[Internet]. 2009; 27(58): 207-217. Available from: http://www2.pucpr.br/reol/index.php/PA?dd1=3248\&dd99=view.

[21] Barhan EJ. Retorno ao trabalho após o nascimento de um filho: percepções de professoras sobre sua experiência. São Carlos, 2010. Biblioteca virtual de Teses e Disertações da Universidade Federal de São Carlos. Available from: http://200.136.241.2:8080/jspui/handle/1/1110

[22] Mattar R, Silva EYK, Camano L, Abrahão AR, Colás OR, Neto JA, Lippi UG. A violência doméstica como indicador de risco no rastreamento da depressão pós-parto. Revista Brasileira de Ginecologia e Obstetrícia. 2007; 29(9): 470-477. http://dx.doi.org/10.1590/S0100-72032007000900006

[23] Corrêa ACP, Arruda TM, Mandú ENT, Teixeira RC, Arantes RB. Humanização da assistência a puérpera: concepções de profissionais de enfermagem de um hospital público. Revista Ciência Cuidado e Saúde. 2010; 9(4): 728-735.

[24] Freitas F, Costa SHM, Lopes JG. Rotinas em obstetrícia. Porto Alegre: Artmed. 2006; 324

[25] Catafesta F, Martins M, Zagonel IPS, Venturi KK. A amamentação na transição puerperal: o desvelamento pelo método pesquisa-cuidado. Revista Escola Ana Nery. 2009; 13(3): 609-616. http://dx.doi.org/10.1590/S1414-81452009000300022.

[26] Pereira MC, Garcia ESGF, Andrade MBT, Gradim CVC. Sentimentos da puérpera primípara nos cuidados com o recém-nascido. Revista Cogitare Enfermagem. 2012; 17(3): 537-42.

[27] Duman NB, Karatas N. The effect of home care services on maternal health after cesarean delivery in Turkey. Journal of Nursing Education and Practice. 2012; 2(4): 124-133. 